\title{
Government Abuses of Human Rights
}

\author{
Susan Mapp ${ }^{1} \cdot$ Shirley Gatenio Gabel ${ }^{2}$
}

Published online: 7 June 2017

(C) Springer International Publishing 2017

The beginning of 2017 has seen a number of alarming government actions around the world that violate human rights. A selection of examples includes the Philippines, Chechnya, Hungary, and the USA, underscoring the vast amount of work to be done to secure human rights for all.

In the Philippines, President Duterte has been promoting extrajudicial killings of suspected drug traffickers and users. As of March 2017, an estimated 8000 had been killed by security forces or vigilantes since his June 2016 inauguration ("Phillipines says," 2017). Amnesty International (2017) states that police, acting on orders from the top echelons of government, have killed and paid others to kill these alleged drug offenders, with a particular focus on the poor and defenseless. President Duterte ran his campaign on the promise to kill drug offenders and on August 6, he stated as an open message to drug offenders, "My order is shoot to kill you. I do not care about human rights, you better believe me."

In Chechnya, the United Nations stated that officials had opened a detention center for gay and bisexual men. They stated that Chechnyan officials were abducting, beating, and killing these men. The UN experts stated detainees were physically and verbally abused, tortured with electric shocks, and forced to disclose the names of others in their community. In Chechnya, being gay or bisexual is highly stigmatized and can

Susan Mapp

mapps@etown.edu

Shirley Gatenio Gabel

gateniogabe@fordham.edu

1 Department of Social Work, Elizabethtown College, Elizabethtown, PA, USA

2 Fordham University, New York, NY, USA leave men vulnerable to being murdered if their orientation is revealed (Chan 2017). When demonstrators protested these actions, they were arrested (Kramer 2017b, May 1). Chechyan officials stated that these allegations of detention could not possibly be true as there are no gay men in Chechnya (Kramer 2017a, April 23).

Hungary has established detention camps for all asylum seekers that are surrounded by razor wire. The United Nations has stated that detention of those who are claiming asylum for the entire length of the time to process their claim violates human rights obligations- "Under International and EU laws, the detention of refugees and asylum seekers can only be justified on a limited number of grounds, and only where it is necessary, reasonable, and proportionate" and that children should never be detained (UNHCR 2017, para. 5). Additionally, there are strict limits on who is even allowed into the camps to have their asylum claims processed-10 a day and only on weekdays (Lyman 2017).

In the USA, approximately 1 week after taking office as the president, Donald Trump signed an Executive Order barring migration from seven predominantly Muslim countries for 90 days, and halting all refugee entry into the USA for 120 days and refugees from Syria indefinitely. This included those who have legal permanent residence in the USA, known as "green card holders." The order became known as the "Muslim ban" because the countries that migration was banned from were Muslim majority nations as well as the fact that it called for prioritizing resettling refugees who are religious minorities in their home countries, i.e., non-Muslims. Both this Order, as well as its follow-up which removed the prioritization of non-Muslims, as well as removing Iraq from the banned list, were blocked by federal judges as unconstitutional ("Trump travel ban," 2017). The International Federation of Social Workers (IFSW) spoke out against the ban, as well as signaling concern that, "the areas of LGBTQ 
rights, climate change, and the translation options into Spanish language, all have been removed from the official White House web page" (IFSW 2017, para. 4).

These brief summaries illustrate that human rights can never be taken for granted in any nation. The articles in this double issue span four continents and a wide variety of issues, further illustrating the broad work that needs to be done and how social workers are working to improve human rights concerns around the globe. As co-editors, we encourage all social workers, allied professions, and all peoples to continue this work of fighting for human rights.

\section{References}

Amnesty International. (2017). Philippines: The police's murderous war on the poor. Retrieved from https://www.amnesty.org/en/latest/ news/2017/01/philippines-the-police-murderous-war-on-the-poor/.

Chan, S. (2017). U. N. experts condemn killing and torture of gay men in Chechnya. New York Times. Retrieved from.
International federation of Social Workers. (2017). Trump's interference with human and social rights. Retrieved from http://ifsw.org/news/ trumps-interference-with-human-and-social-rights/.

Kramer, A. E. (2017a). Reporting on people who 'don't exist'. New York Times. Retrieved from https://www.nytimes.com/2017/04/23/ insider/russia-chechnya-gays.html.

Kramer, A. E. (2017b). Russians protesting abuse of gay men in Chechnya are detained. New York Times. Retrieved from https:// www.nytimes.com/2017/05/01/world/europe/russia-gay-rightschechnya.html.

Lyman, R. (2017). Already unwelcoming, Hungary now detains asylum seekers. New York Times. Retrieved from https://www.nytimes.com/ 2017/04/18/world/europe/hungary-orban-populism-migrantsborder-european-union.html.

Philippines says condemns extrajudicial killings, but none during drugs war. (2017). Reuters. Retrieved from http://www.reuters.com/ article/us-philippines-drugs-usa-idUSKBN16B0KL.

Trump travel ban: Second US judge block new executive order. (2017). $B B C$. Retrieved from http://www.bbc.com/news/world-us-canada39287656.

UNHCR. (2017). UNHCR deeply concerned by Hungary plans to detain all asylum seekers. Retrieved from http://www.unhcr.org/uk/news/ briefing/2017/3/58be80454/unhcr-deeply-concerned-hungaryplans-detain-asylum-seekers.html. 